\title{
Granulosa cell tumor of the ovary and antecedent of adjuvant tamoxifen use for breast cancer
}

\author{
Halima Abahssain ${ }^{1 *}$, Mouna Kairouani ${ }^{1}$, Robert Gherman², Hind M'Rabti ${ }^{1}$, Hassan Errihani ${ }^{1}$
}

\begin{abstract}
Background: Adult granulosa cell tumor associated with antecedent use of tamoxifen as adjuvant hormonotherapy for breast cancer is rare. The pathogenesis of this occurrence remains difficult to explain. The estrogenic effect of tamoxifen can be one such explanation.

Case presentation: A 47 year-old women was treated with surgery, chemotherapy, radiotherapy and tamoxifen for stage III estrogen receptor positive breast carcinoma. Ten months after stopping tamoxifen, we diagnosed a stage Ic granulosa cell tumor of the ovary.

Conclusions: Use of tamoxifen has been found to be associated with gynecological tumors like endometrial carcinoma. Its association with granulosa cell tumor of the ovary is uncommon. Only two previous cases have been reported in literature.
\end{abstract}

\section{Background}

Granulosa cell tumor is a relatively uncommon ovarian neoplasm accounting for $1 \%$ to $2 \%$ of all ovarian tumors [1]. Tamoxifen is a non steroidal triphenylethylene that competitively antagonizes the binding of estradiol to estrogen receptor-positive breast carcinoma[2-5]. The occurrence of granulosa cell tumors in patients with antecedent tamoxifen has been previously reported in two patients[6,7]. Although tamoxifen has anti-estrogenic properties, it is converted to several metabolites that can act as estrogen agonists [6]. We report the third case of granulosa cell tumor of the ovary associated with tamoxifen use for breast carcinoma.

\section{Case presentation}

A 47-year-old gravidia 3, para 3 women with chemotherapy induced menopause, had been diagnosed with stage III(T2 N2M0) infiltrating ductal carcinoma of the right breast 5 years before the development of a bilateral granulosa cell tumor of the ovary. After Patey's mastectomy, patient has received 6 cycle of anthracycline based chemotherapy (AC 60 protocol: adriamycin

\footnotetext{
* Correspondence: abahssainhalima@yahoo.fr

${ }^{1}$ Service of medical oncology, National institute of oncology, Rabat, Morocco Full list of author information is available at the end of the article
}

at $60 \mathrm{mg} / \mathrm{m}^{2}$ and cyclophosphamide at $600 \mathrm{mg} / \mathrm{m}^{2}$ ) and adjuvant radiotherapy at a cumulative dose of $50 \mathrm{~Gy}$. The estrogen receptors were strongly positive and the patient received tamoxifen at a dose of $20 \mathrm{mg}$ as single daily dose since January 2004. The tamoxifen was stopped after 5 years. In February 2009, one month after that the patient has stopped the tamoxifen therapy, a nodule in the left ovary was discovered during a laparoscopy for tubal ligation. A left oopherectomy was done, the pathological results showed a granulosa cell tumor. Following this a total hysterectomy, right salpingooophorectomy, omentectomy, pelvic and peritoneal washings and multiple peritoneal biopsies were done. The histopathological analysis showed a granulosa cell tumor of the right ovary with capsular rupture in the left ovary, moderate nuclear atypia and mitotic activity ranged between 3 and 5 per ten high-power-fields. Histological evaluation of uterus showed a proliferative endometrial lining. The tumor was classified as stage Ic according to the FIGO classification. The case of our patient was discussed in the multidisciplinary meeting and it was decided to keep her on a close follow-up. Thirteen months after initial diagnosis of granulosa cell of the ovary, she is free of disease. 


\section{Discussion}

The granulosa cell tumor is a relatively uncommon ovarian neoplasm accounting $1 \%$ to $2 \%$ of all ovarian tumors [1]. These lesions occur most frequently in menopausal or postmenopausal women and may be associated with symptoms of estrogen or progesterone secretion [1]. The relationship between this hormonal treatment and the occurrence of such an ovarian tumor is questionable, as so many patients worldwide receive tamoxifen therapy and only two previous cases has been reported in literature till date. It's probable that the association of granulosa cell tumor and the use of tamoxifen for breast cancer is just a random observation and there is no relationship between them.

As mentioned earlier, the granulosa cell tumors in conjunction with tamoxifen administration for breast cancer have been reported in literature. The first case was reported in 1994 by Gherman et al [6] in a 52-yearold woman. This patient had liver dysfunction induced by tamoxifen. The authors suggested that the impaired hepatic metabolism of the tamoxifen may be responsible for the ovarian tumor in their patient with elevated liver transaminase levels. The second case was reported in 2002 by Arnould et al [7]; they described a case of metastases of a breast carcinoma to an adult granulosa cell tumor in a 63-year-old woman receiving tamoxifen therapy with a past history of breast carcinoma. No explanation was provided for the occurrence and that was only the second case in the literature despite that the tamoxifen being used by a large number of patients around the world with breast cancer. Tamoxifen is an anti-oestrogenic non-steroidal compound widely used for adjuvant therapy in breast cancer [8]. Its proven efficacy as a chemotherapeutic agent has led to its prophylactic use in the prevention of breast cancer in healthy women at high risk of developing breast cancer and it has also shown efficacy in this regard [9]. Despite these anticarcinogenic properties, tamoxifen is also a carcinogen. Women, who take tamoxifen, whether therapeutically or prophylactically, are at significantly increased risk of endometrial cancer [9-11]. Tamoxifen is also a potent liver carcinogen in male and female rats [12], and induces uterine tumors when administered to neonatal $[13]$ and adult rats $[14,15]$. These findings suggest an appropriate surveillance of these patients treated with tamoxifen in order to proceed to an early diagnosis of secondary gynecological cancers.

Tamoxifen is subject to extensive hepatic metabolism. Not surprisingly, several of the metabolites are predominately estrogenic, rather than antiestrogenic. Differences in tamoxifen metabolism among mice, rats, and humans probably contribute to variation among species-agonist versus partial agonist properties [16].
The metabolite $\mathrm{E}$ is generated by the catabolism of tamoxifen, which has a lower affinity for estrogen receptors than tamoxifen [17-19]. However the cis isomer of metabolite $\mathrm{E}$ (tamoxifen with a hydroxyl group in place of the dimethylaminoethane side chain) is a potent agonist that displays a high affinity for the estrogen receptor $[5,20]$. This metabolite has been isolated from dog bile, a species where tamoxifen is predominantly estrogenic. Wiebe et al have identified metabolite $\mathrm{E}$ and bisphenol in tamoxifen resistant MCF-7 human breast tumors implanted in athymic nude mice, as well as in tumors isolated from patients who have undergone unsuccessful tamoxifen therapy [21,22]. Tamoxifen is known to exhibit estrogenic effects in other animal species. Tucker et al were showed in the studies of tamoxifen oncogenicity an elevated of the incidence of granulosa cell tumors at $36 \%$ in two groups of female mice receiving 5 or $50 \mathrm{mg} / \mathrm{kg}$ of tamoxifen [23]. In their study on cultured rat granulosa cells, welsh et al proved that tamoxifen exerts an augmentative, dose-dependent estrogenic effect on FSH-stimulated aromatase activity and estrogen production. They demonstrated that tamoxifen compete with $[3 \mathrm{H}]$ estradiol for binding to the ovarian estrogen receptors [24].

Raloxifene and tamoxifen are Selective estrogen receptor modulators (SERMs) that have estrogen agonist activities on bone and serum lipid metabolism, and estrogen antagonist activities in mammary tissue in ovariectomized rats [25-27]. Treatment with raloxifene for 6 months resulted in disruption of the hypothalamic-pituitary-ovarian axis, manifested by increased plasma concentrations of luteinizing hormone $(\mathrm{LH})$ and estradiol-17b (E2), and failure of ovulation. Many (56\% to $80 \%)$ rats in all raloxifene treated groups had focal, minimal to slight hyperplasia of granulosa cells within individual retained follicles. A few treated rats in the mid- and high-dose groups had more extensive focal proliferation of granulosa cells. The results of this study indicate that raloxifene administration to rats causes increases in granulosa cell hyperplasia [25].

\section{Conclusions}

Association between granulosa cell of the ovary and antecedent use of tamoxifen is very rare. When compared to world wide tamoxifen use among women, it appears to be just a random appearance and tamoxifen use does not appear to increase the risk of granulosa cell tumor of the ovary.

\section{Consent}

Written informed consent was obtained from the patient for publication of this case report and accompanying images. A copy of the written consent is available for review by the Editor-in-Chief of this journal. 


\section{Competing interests}

The authors declare that they have no competing interests.

\section{Authors' contributions}

HA was responsible for the conception and design for the manuscript, the clinical work, the search for the literature, and the editing work. MK helped in the clinical work as well as the literature review. HM edited the manuscript. HE provided overall supervision and contributed to concept, writing and approval of final version for publication.

\section{Author details}

'Service of medical oncology, National institute of oncology, Rabat, Morocco. 2Division of Maternal and Foetal Medicine, Prince George's Hospital Centre, Cheverly, USA.

Received: 13 April 2010 Accepted: 12 August 2010

Published: 12 August 2010

\section{References}

1. Scully RE, Young RH, Clement PB: Sex cord-stromal tumors, granulosa cell tumors and secondary tumors. Atlas of Tumor Pathology, 3rd Series, Fascicle 23 Washington, DC, Armed Forces Institute of PathologyRosai J, Sobin LH 1998, 169-188, Tumors of the Ovary, Maldeveloped Gonads, Fallopian Tube, and Broad Ligament, 349-352.

2. Fornander T, Rutqvist $L E$, Cedermark B, Glas U, Mattsson A, Silfverswärd C, Skoog L, Somell A, Theve T, Wilking N, et al: Adjuvant tamoxifen in early breast cancer: occurrence of new primary cancers. Lancet 1989, 1(8630):117-20.

3. Powles TJ, Hardy JR, Ashley SE, Farrington GM, Cosgrove D, Davey JB, Dowsett M, McKinna JA, Nash AG, Sinnett HD, et al: A pilot trial to evaluate the acute toxicity and feasibility of tamoxifen for prevention of breast cancer. Br J Cancer 1989, 60(1):126-31.

4. Fisher B, Costantino JP, Redmond CK, Fisher ER, Wickerham DL, Cronin WM: Endometrial cancer in tamoxifen-treated breast cancer patients: findings from the National Surgical Adjuvant Breast and Bowel Project (NSABP) B-14. J Natl Cancer Inst 1994, 86(7):527-37.

5. Jordan VC: Biochemical pharmacology of antiestrogen action. Pharmacol Rev 1984, 36(4):245-76

6. Gherman RB, Parker MF, Macri Cl: Granulosa cell tumor of the ovary associated with antecedent tamoxifen use. Obstet Gynecol 1994, 84:717-719.

7. Arnould L, Franco N, Soubeyrand MS, Mege F, Belichard C, Lizard-Nacol S, Collin F: Breast carcinoma metastasis within granulosa cell tumor of the ovary: morphologic, immunohistologic, and molecular analyses of the two different tumor cell populations. Hum Pathol 2002, 33(4):445-8.

8. Early Breast Cancer Trialists' Collaborative Group: Tamoxifen for early breast cancer: an overview of the randomized trials. Lancet 1998, 351:1451-1467.

9. Cuzick J, Powles T, Veronesi U, Forbes J, Edwards R, Ashley S, Boyle P. Overview of the main outcomes in breast-cancer prevention trials. Lancet 2003, 361:296-300.

10. IARC Tamoxifen. IARC Monographs on the Evaluation of Carcinogenic Risk to Humans, Some Pharmaceutical Drugs International Agency for Research on Cancer, Lyon, France 1996, 66:253-365.

11. Swerdlow AJ, Jones ME: Tamoxifen treatment for breast cancer and risk of endometrial cancer: a case-control study. J Natl Cancer Inst 2005, 97:375-384.

12. Greaves P, Goonetilleke R, Nunn G, Topham J, Orton T: Two-year carcinogenicity study of tamoxifen in Alderley Park Wistar-derived rats. Cancer Res 1993, 53:3919-3924.

13. Carthew P, Edwards RE, Nolan BM, Martin EA, Heydon RT, White INH, Tucker MJ: Tamoxifen induces endometrial and vaginal cancer in rats in the absence of endometrial hyperplasia. Carcinogenesis 2000, 21:793-797.

14. Mäntylä E, Nieminen L, Karlsson S: Endometrial cancer induction by tamoxifen in the rat. Eur J Cancer 1995, 31(A suppl. 6):S14.

15. Phillips DH, Hewer A, Osborne MR, Cole KJ, Churchill C, Arlt VM: Organ specificity of DNA adduct formation by tamoxifen and alphahydroxytamoxifen in the rat: implications for understanding the mechanism(s) of tamoxifen carcinogenicity and for human risk assessment. Mutagenesis 2005, 20(4):297-303.
16. Jordan VC, Robinson SP: Species-specific pharmacology of antiestrogens: Role of metabolism. Fed Proc 1987, 46:1870-1874.

17. Buckely MMT, Goa KL: Tamoxifen: A reappraisal of its pharmacodynamic and pharmacokinetic properties, and therapeutic use. Drugs 1989, 37:451-490.

18. Lonning PE, Hall K, Aakvaag A, Lien EA: Influence of tamoxifen on plasma levels of insulin-like growth factor I and insulin-like growth factor binding protein I in breast cancer patients. Cancer Res 1992 52:4719-4723.

19. Kemp JV, Adam HK, Wakeling AE, Slater R: Identification and biological activity of tamoxifen metabolites in human serum. Biochem Pharmacol 1983, 32:2045-2052.

20. Wolf DM, Jordan VC: Gynecologic complications associated with longterm adjuvant tamoxifen therapy for breast cancer. Gynecol Oncol 1992, 45(2):118-28.

21. Wiebe VJ, Osborne CK, McGuire WL, DeGregorio MW: Identification of estrogenic tamoxifen metabolite(s) in tamoxifen-resistant human breast tumors. J Clin Oncol 1992, 10(6):990-4.

22. Osborne CK, Wiebe VJ, McGuire WL, Ciocca DR, DeGregorio MW: Tamoxifen and the isomers of 4-hydroxytamoxifen in tamoxifen-resistant tumors from breast cancer patients. J Clin Oncol 1992, 10(2):304-10.

23. Tucker MJ, Adam HK, Patterson HS, Laurence DR, McLean AEH, Weatherall M: Tamoxifen Safety testing of new drugs. Laboratory predictions and clinical performance. New York: Harcourt, Brace and Jovanovich Publishers 1984, 125-61.

24. Welsh TH Jr, Jia XC, Jones PB, Zhuang LZ, Hsueh AJ: Disparate effects of triphenylethylene antiestrogens on estrogen and progestin biosyntheses by cultured rat granulosa cells. Endocrinology 1984, 115(4):1275-82.

25. Long GG, Cohen IR, Gries CL, Young JK, Francis PC, Capen CC: Proliferative lesions of ovarian granulosa cells and reversible hormonal changes induced in rats by a selective estrogen receptor modulator. Toxicol Pathol 2001, 29(6):719-26.

26. Sato M, Rippy MK, Bryant HU: Raloxifene, tamoxifen, nafoxidine, or estrogen effects on reproductive and nonreproductive tissues in ovariectomized rats. FASEB J 1996, 10:905-912.

27. Frolik CA, Bryant HU, Black EC, Magee DE, Chandrasekhar S: Timedependent changes in biochemical bone markers and serum cholesterol in ovariectomized rats: Effects of raloxifene $\mathrm{HC1}$, tamoxifen, estrogen, and alendronate. Bone 1996, 18:621-627.

doi:10.1186/1477-7819-8-67

Cite this article as: Abahssain et al:: Granulosa cell tumor of the ovary and antecedent of adjuvant tamoxifen use for breast cancer. World Journal of Surgical Oncology 2010 8:67.

\section{Submit your next manuscript to BioMed Central and take full advantage of:}

- Convenient online submission

- Thorough peer review

- No space constraints or color figure charges

- Immediate publication on acceptance

- Inclusion in PubMed, CAS, Scopus and Google Scholar

- Research which is freely available for redistribution
C Biomed Central 